American Journal of Applied Sciences 6 (1): 101-108, 2009

ISSN 1546-9239

(C) 2009 Science Publications

\title{
Analysis of Heat Transport in a Proton Exchange Membrane (PEM) Fuel Cell
}

\author{
E. Afshari and S.A. Jazayeri \\ Department of Mechanical Engineering, \\ K.N. Toosi University, P.O. Box 19395-1999, Tehran, Iran
}

\begin{abstract}
In this study a two-phases, single-domain and non-isothermal model of a Proton Exchange Membrane (PEM) fuel cell has been studied to investigate thermal management effects on fuel cell performance. A set of governing equations, conservation of mass, momentum, species, energy and charge for gas diffusion layers, catalyst layers and the membrane regions are considered. These equations are solved numerically in a single domain, using finite-volume-based computational fluid dynamics technique. Also the effects of four critical parameters that are thermal conductivity of gas diffusion layer, relative humidity, operating temperature and current density on the PEM fuel cell performance is investigated. In low operating temperatures the resistance within the membrane increases and this could cause rapid decrease in potential. High operating temperature would also reduce transport losses and it would lead to increase in electrochemical reaction rate. This could virtually result in decreasing the cell potential due to an increasing water vapor partial pressure and the membrane water dehydration. Another significant result is that the temperature distribution in GDL is almost linear but within membrane is highly non-linear. However at low current density the temperature across all regions of the cell dose not change significantly. The cell potential increases with relative humidity and improved hydration which reduces ohmic losses. Also the temperature within the cell is much higher with reduced GDL thermal conductivities. The numerical model which is developed is validated with published experimental data and the results are in good agreement.
\end{abstract}

Key words: PEM fuel cell, temperature, two-phase, single-domain

\section{INTRODUCTION}

The proton exchange membrane (PEM) fuel cell is a promising alternative to traditional power sources for a wide range of portable, automotive and stationary applications. The advantages of PEM fuel cell include the ability to provide high current densities at relatively low operating temperature, quick start-up, immediate response to changes in the demand for power and emission-free operation ${ }^{[1]}$. The high cost and relatively low reliability of fuel cell are the limiting factors for their widespread use. A better understanding of operating conditions in PEM fuel cell is essential to the development and optimization of fuel cells, the introduction of cheaper materials and fabrication techniques and the design and development of novel architectures.

Thermal management is very important in overall cell performance. The increase in the cell temperature could be beneficial or harmful to fuel cell performance. Since it increases electrochemical reaction rate and higher mass transfer rate, but usually lowers cell ohmic resistance arising from the higher ionic conductivity of the membrane. Instead, it may lead to increased mass transport losses due to the increase in water vapor pressure. In addition it may cause drying out of the membrane, which in turn can result not only in reduced performance but also in eventual rupture of the membrane. The decrease in the temperature can be beneficial or harmful to fuel cell performance since the low temperature allows the PEM fuel cell to have a quick start-up time compared to other fuel cell systems. Instead it could hamper the reaction rate which in turn could increase the losses and flooding of the membrane ${ }^{[1]}$. Therefore temperature changes could reduce the performance of the PEM fuel cell where thermal management is critically important. Because of the highly reactive environment and compact nature of a fuel cell, it is hard to conduct calorimetric measurements to obtain the thermal data within a fuel cell. The transport phenomena are quite complex due to the coupling of convective heat and mass transport with phase change, porous media and electrochemistry in a fuel cell. This information is usually sought through

Corresponding Author: E. Afshari, Department of Mechanical Engineering, K.N. Toosi University, P.O. Box 19395-1999, Tehran, Iran Tel: 98-21-88674841 Fax: 98-21-88674844 
modeling or simulation. Recent works are directed towards better understanding of the cell operation and performance $^{[2-11]}$. Mostly the electrochemical reactions are assumed as an adiabatic process ${ }^{[2-3]}$ and some work considered the thermal-fluid transport in the porous electrode $^{[4-11]}$. Researchers have developed mathematical models to gain qualitative insights into the processes involved in the PEM fuel cells. Many mathematical models have been presented, but these models either treated the catalyst layer as an ultrathin interface or did not fully account for the effect of liquid water in the PEM fuel cell. Although modeling of transport and electrochemical phenomena has been considered extensively in the literature and provides good insight on fuel cell operation, but still a complete model of non-isothermal, two-phase and single-domain to determine temperature and the effect of thermal management on the performance of PEM fuel cell dose not exist. In this work a non-isothermal, two phases and single-domain, one-dimensional with the coupled electrochemical and thermal phenomena and unsaturated reactant gas streams is modeled in a fivelayer membrane-electrode assembly of a PEM fuel cell to analyze the impact of cell voltage, operating temperature, relative humidity and GDL thermal conductivity on thermal behaviors of PEM fuel cell.

Model description: A typical PEM fuel cell layout is given in Fig. 1. The computational domain consists of anode and cathode gas diffusion layers (aGDL, cGDL), anode and cathode catalyst layers (aCL, cCL) and a proton exchange membrane (PEM). Humidified hydrogen and saturated air are supplied by the anodic gas channel and the cathodic gas channel, respectively. In the anodic catalyst layer, hydrogen is consumed to

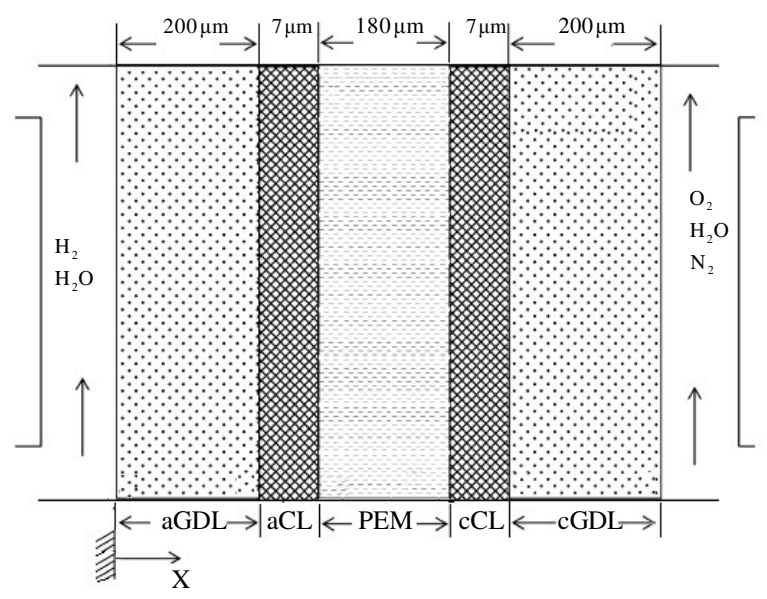

Fig. 1: Sectional view of the fuel cell module form protons and electrons that protons carry the ionic current to the cathode. However the electrons travel through the conductive diffusion layer and an external circuit that finally produces electric work. In the cathodic catalyst layer, the electrochemical reaction not only consumes the oxygen but also produces the heat and water.

The assumptions used in the model are: the model is one-dimentional and steady state, the reactant gas mixtures are ideal gases, the gas flow is laminar and incompressible with variable density, the Soret, Dufour, gravity and radiation effects are neglected, the catalyst is uniformly distributed in both the cathode and anode catalyst layers, The gas diffusion layer is assumed to be isotropic and homogenous and the viscosity of the gas mixture is constant and calculated from the inlet conditions. In contrast to usual approach which employs separate differential equations for different regions, we have taken a single-domain approach in which a sin gle set of governing equations valid for all regions. Therefore, no interfacial conditions are required to be specified at internal boundaries between these regions. The governing equations include conservation of mass, momentum, ionic charge and energy as well as individual species. The conservation of mass for all gas species are presented in Eq. 1. The source terms reflect changes in the overall gas phase mass due to consumption or production of gas species resulting from reaction and mass transfer between the water in the gas phase and that dissolved in the polymer. The gas mixture density is expressed as the sum of the individual species concentrations multiplied by their respective molar masses:

$$
\nabla \cdot\left(\rho^{\mathrm{g}} \overline{\mathrm{u}}\right)=\mathrm{S}_{\mathrm{H}_{2}}+\mathrm{S}_{\mathrm{O}_{2}}+\mathrm{S}_{\text {vap }}+\mathrm{S}_{\text {diss }}+\mathrm{S}_{\mathrm{lv}}
$$

The momentum equations, Eq. 2, are NavierStokes equations express in vector form, modified with a source term to account for Darcy flow in the porous regions:

$$
\overline{\mathrm{u}} . \nabla\left(\rho^{\mathrm{g}} \overline{\mathrm{u}}\right)=-\nabla \mathrm{p}+\mu \nabla^{2} \overline{\mathrm{u}}+\mathrm{S}_{\text {Dar }}
$$

The gas species (hydrogen, oxygen, nitrogen, water vapour) transport equations are given in Equation (3). Each of these equations has an advective term equal to the product of velocity and concentration gradient. The source terms for hydrogen and oxygen species account for consumption due to reaction. Also the source term for water vapor accounts for production of water at the cathode: 
Am. J. Applied Sci., 6 (1): 101-108, 2009

$$
\left\{\begin{array}{c}
\nabla \cdot\left(\mathrm{D}_{\mathrm{H}_{2}} \nabla \mathrm{c}_{\mathrm{H}_{2}}\right)-\overline{\mathrm{u}} \nabla \mathrm{c}_{\mathrm{H}_{2}}+\mathrm{S}_{\mathrm{H}_{2}}=0 \\
\nabla \cdot\left(\mathrm{D}_{\mathrm{O}_{2}} \nabla \mathrm{c}_{\mathrm{O}_{2}}\right)-\overline{\mathrm{u}} \nabla \mathrm{c}_{\mathrm{O}_{2}}+\mathrm{S}_{\mathrm{O}_{2}}=0 \\
\nabla \cdot\left(\mathrm{D}_{\mathrm{N}_{2}} \nabla \mathrm{c}_{\mathrm{N}_{2}}\right)-\overline{\mathrm{u}} \nabla \mathrm{c}_{\mathrm{N}_{2}}=0 \\
\nabla .\left(\mathrm{D}_{\left.\mathrm{H}_{2} \mathrm{O} \text { (vap }\right)} \nabla \mathrm{c}_{\mathrm{H}_{2} \mathrm{O} \text { (vap) }}\right)-\overline{\mathrm{u}} \nabla \mathrm{c}_{\mathrm{H}_{2} \mathrm{O} \text { (vap) }}+\mathrm{S}_{\mathrm{lv}}+\mathrm{S}_{\text {vap }}+\mathrm{S}_{\text {diss }}=0
\end{array}\right.
$$

Liquid water transport within the cell is modelled with Eq. 4. The variable that describes liquid water is the saturation, $s$, which is the volume fraction of liquid water relative to the pore volume in the porous sections of the fuel cell. Within the porous electrodes; liquid water is transported by capillary pressure and interphase mass transfer. The diffusion coefficient for liquid water, accounts for water motion via capillary pressure and is based on a semi-empirical relation between capillary pressure and saturation. Water is exchanged with the liquid phase, assumed that is due to evaporation into the vapor:

$$
\nabla .\left(\mathrm{D}_{\mathrm{H}_{2} \mathrm{O}(1)} \nabla \mathrm{s}\right)-\overline{\mathrm{u}} \nabla \mathrm{s}-\mathrm{S}_{\mathrm{lv}} / \rho_{\mathrm{H}_{2} \mathrm{O}(1)}=0
$$

The transport equation for dissolved water is given in Eq. 5. Water exists in dissolved form within the polymer membrane and a portion of the polymer phase of the catalyst layer. Dissolved water is transported through the polymer by diffusion and electro-osmotic drag only. A source term is needed to account for mass transfer between the dissolved and vapor phases within the catalyst layer.

$$
\nabla .\left(\mathrm{D}_{\mathrm{m}} \nabla \mathrm{c}_{\mathrm{m}}\right)-\mathrm{S}_{\mathrm{drag}}-\mathrm{S}_{\mathrm{diss}}=0
$$

The transport of protons in the polymer portions of the fuel cell is described by Eq. 6. The source term represents the production/consumption of protons due to electrochemical reactions in the catalyst layers. The rate of the electrochemical reaction is described by the
Butler-Volmer relation. It is set to zero on the anode side and in the cathode side is the difference between the cell voltage and open circuit voltage.

$$
\nabla \cdot\left(\sigma_{\mathrm{m}} \nabla \varphi_{\mathrm{m}}\right)=\mathrm{S}_{\mathrm{pc}}
$$

The energy equation is presented in Eq. 7 and contains sources for ohmic heating due to ionic resistance, reversible heat, heat produced due to activation losses and heat exchange involved in the phase change of water. There are two terms related to energy needed for phase change. The first term is the energy required to vaporization the water and the other term accounts for water moving between two phases. The enthalpy of the water dissolved in the polymer is assumed to be the same as the enthalpy of liquid water.

$$
\nabla .\left(\mathrm{k}^{\text {eff }} \nabla \mathrm{T}\right)-\rho^{\mathrm{g}} \mathrm{c}_{\mathrm{p}}^{\mathrm{eff}} \overline{\mathrm{u}} \nabla \mathrm{T}+\mathrm{S}_{\text {ohm }}(+\mathrm{S})_{\text {rev }}+\mathrm{S}_{\mathrm{act}}-\mathrm{S}_{\mathrm{wv}}-\mathrm{S}_{\text {evep }}=0
$$

Source terms and electrochemical and physical properties are listed in Table 1-3.

Boundary conditions: Due to the single-domain formulation, boundary conditions are required only at the external surfaces of computational domain. The temperature, pressure, humidity, flow rate in stoichiometric rate and composition of the reactant gas in both anode and cathode channels are specified according to the cell operating conditions. The mole fractions of gas species at the interfaces between gas

\begin{tabular}{|c|c|c|}
\hline & Defining equation* & Region of application \\
\hline Darcy pressure drop $\left(\mathrm{Pa} \mathrm{m}^{-1}\right)$ & $\mathrm{S}_{\mathrm{Dar}}=-\left(\mathrm{m} \mathrm{K}^{-1}\right) A$ & aGDL, cGDL, aCL, cCL \\
\hline Hydrogen consumption $\left(\mathrm{kg} \mathrm{m}^{-3} \mathrm{sec}\right)$ & $\mathrm{S}_{\mathrm{H} 2}=-\left(\mathrm{M}_{\mathrm{H} 2} \mathrm{nF}^{-1}\right) \mathrm{j}$ & $\mathrm{aCL}$ \\
\hline Oxygen consumption $\left(\mathrm{kg} \mathrm{m}^{-3} \mathrm{sec}\right)$ & $\mathrm{S}_{\mathrm{O} 2}=-\left(\mathrm{M}_{\mathrm{O} 2} \mathrm{nF}^{-1}\right) \mathrm{j}$ & $\mathrm{cCL}$ \\
\hline Mass transfer rate from liquid to vapor $\left(\mathrm{kg} \mathrm{m}^{-3} \mathrm{sec}\right)$ & Slv $=\psi s$ & aGDL, cGDL, aCL, cCL \\
\hline Vapor/dissolved water mass transfer $\left(\mathrm{kg} \mathrm{m}^{-3} \mathrm{sec}\right)$ & $\mathrm{S}_{\mathrm{diss}}=\mathrm{h}_{\text {mass }}\left(\rho_{\mathrm{sat}}-\rho_{\mathrm{H}_{2} \mathrm{O}}\right)$ & $\mathrm{cCL}$ \\
\hline Water vapor production $\left(\mathrm{kg} \mathrm{m}^{-3} \mathrm{sec}\right)$ & $\mathrm{S}_{\text {vap }}=\left(\mathrm{M}_{\mathrm{H}_{2} \mathrm{O}} / 2 \mathrm{~F}\right) \mathrm{j}$ & $\mathrm{cCL}$ \\
\hline Protonic current $\left(\mathrm{A} \mathrm{m}^{-3}\right)$ & $S_{\mathrm{pc}}=-\mathrm{j}$ & $\mathrm{aCL}, \mathrm{cCL}$, \\
\hline Ohmic heating $\left(\mathrm{A} \mathrm{m}^{-3}\right)$ & $\mathrm{S}_{\mathrm{ohm}}=-\left(\sigma_{\mathrm{m}} \partial \varphi_{\mathrm{m}} / \partial \mathrm{x}\right)^{2}\left(1 / \sigma_{\mathrm{m}}\right)$ & $\mathrm{aCL}, \mathrm{cCL}$ \\
\hline Reversible heat $\left(\mathrm{A} \mathrm{m}^{-3}\right)$ & $\mathrm{S}_{\mathrm{rev}}=\mathrm{j} / \mathrm{nF} \mid(\mathrm{T} \Delta \mathbf{\square})$ & $\mathrm{aCL}, \mathrm{cCL}$ \\
\hline Heat due to phase change $\left(\mathrm{A} \mathrm{m}^{-3}\right)$ & $\mathrm{S}_{\text {evap }}=\mathrm{h}_{\mathrm{vap}}\left(-\mathrm{S}_{\mathrm{lv}}+\mathrm{S}_{\text {diss }}\right)$ & $\mathrm{aCL}, \mathrm{cCL}$ \\
\hline Activation loss $\left(\mathrm{A} \mathrm{m}^{-3}\right)$ & $\mathrm{S}_{\mathrm{act}}=\left(\varphi_{\mathrm{s}}-\varphi_{\mathrm{m}}\right) \mathrm{j}$ & $\mathrm{aCL}, \mathrm{cCL}$ \\
\hline Water vaporization $\left(\mathrm{A} \mathrm{m}^{-3}\right)$ & $S_{w v}=(j / 2 F) h_{v a p}$ & $\mathrm{cCL}$ \\
\hline
\end{tabular}
channel and GDL in anode and cathode side are determined based upon the set stoichiometric flow rate of gas and the humidification of the streams. The average composition between inlet and outlet in the channels is determined using an integral mass balance on the gas chambers ${ }^{[10]}$.

Table 1: Source terms for momentum, species, charge and energy conservation in various regions ${ }^{[9]}$ 
Am. J. Applied Sci., 6 (1): 101-108, 2009

Table 2: Electrochemical properties ${ }^{[2,9]}$

\begin{tabular}{lll}
\hline Parameter & Anode & Cathode \\
\hline Transfer current density $\left(\mathrm{A} \mathrm{m}^{-3}\right)$ & $\mathrm{j}=\left(\mathrm{ai}_{0}\right)_{\mathrm{a}}\left(\frac{\mathrm{c}_{\mathrm{H}_{2}}}{\mathrm{c}_{\mathrm{H}_{2}}^{\mathrm{ref}}}\right)^{1 / 2}\left(\frac{2}{\mathrm{RT}} \mathrm{F \eta}\right)$ & $\mathrm{j}=-(\mathrm{ai})_{\mathrm{c}}\left(\frac{\mathrm{c}_{\mathrm{O}_{2}}}{\mathrm{c}_{\mathrm{O}_{2}}}\right) \exp \left(-\frac{1}{\mathrm{RT}} \mathrm{F \eta}\right)$ \\
Surface overpotential $(\mathrm{V})$ & $\eta=\phi_{\mathrm{s}}-\phi_{\mathrm{m}}-\mathrm{U}_{0}\left(\phi_{\mathrm{s}}=0\right)$ & $\eta=\phi_{\mathrm{s}}-\phi_{\mathrm{m}}-\mathrm{U}_{0}\left(\phi_{\mathrm{s}}=\mathrm{V}_{\text {cell }}\right)$ \\
Equilibrium potential $(\mathrm{V})$ & $\mathrm{U}_{0}=0$ & $\mathrm{U}_{0}=1.23-0.9 \times 10^{-3}(\mathrm{~T}-298.15)$ \\
Exchange current density $\times$ reaction surface area $\left(\mathrm{A} \mathrm{m}^{-3}\right)$ & $\left(\mathrm{ai}_{0}\right)_{\mathrm{a}}=1.0 \times 10^{9}$ & $\left(\mathrm{ai}_{0}\right)_{\mathrm{c}}=3.0 \times 10^{3}$ \\
\hline
\end{tabular}

Table 3: Physical and transport properties ${ }^{[2,9]}$

\begin{tabular}{ll}
\hline Parameter & Value \\
\hline Water vapor activity & $\mathrm{a}=\frac{\mathrm{c}_{\mathrm{H}_{2} \mathrm{O}(\text { vap }} \mathrm{RT}}{\mathrm{P}_{\text {sat }}}$ \\
Ionic conductivity of membrane $(\mathrm{S} / \mathrm{m})$ & $\sigma_{\mathrm{m}}=(0.0005139 \lambda-0.000326) \exp \left(1268.0\left(\frac{1}{303}-\frac{1}{\mathrm{~T}}\right)\right)$ \\
Polymer water content $\mathrm{mol}_{2} \mathrm{O} / \mathrm{molSO}_{3}^{-}$ & $\lambda=\left\{\begin{array}{c}0.043+17.81 \mathrm{a}-39.85 \mathrm{a}^{2}+36.0 \mathrm{a}^{3} \quad \text { for } 0<\mathrm{a} \leq 1 \\
14+1.4(\mathrm{a}-1) \text { for } 1<\mathrm{a} \leq 3\end{array}\right.$ \\
Diffusion coefficient for dissolved water $\left(\mathrm{m}^{2} \mathrm{~s}^{-1}\right)$ & $\mathrm{D}_{\mathrm{m}}=1.3 \times 10^{-4} \exp \left(2416\left(\frac{1}{303}-\frac{1}{\mathrm{~T}}\right)\right)$ \\
Diffusion coefficient for liquid water $\left(\mathrm{m}^{2} \mathrm{~s}^{-1}\right)$ & $\mathrm{D}_{\mathrm{H}_{2} \mathrm{O}(1)}=\frac{\rho_{\mathrm{H}_{2} \mathrm{O}}}{\mu_{\mathrm{H}_{2} \mathrm{O}}}\left(0.155 \mathrm{~s}^{3}-0.0213 \mathrm{~s}^{2}+0.0088 \mathrm{~s}+0.0002\right)$ \\
Gas diffusion coefficient in porous media $\left(\mathrm{m}^{2} \mathrm{~s}^{-1}\right)$ & $\mathrm{D}_{\mathrm{k}}=\varepsilon_{\mathrm{i}}^{1.5} \mathrm{D}_{0}\left(\frac{\mathrm{T}}{\mathrm{T}_{0}}\right)^{1.5}\left(\frac{\mathrm{P}}{\mathrm{P}_{0}}\right)$ \\
\hline
\end{tabular}

Numerical procedures: The governing equations, Eq. 1-7, were discretized using a finite volume based finite difference method and solved using a computational fluid dynamic code. In this code the pressure and velocity fields is treated with the SIMPLER pressure correction algorithm, where a single-domain model is used. It should be mentioned that by using this model although some species dose not exist practically in certain regions of fuel cell, the species transport equation can still be applied throughout the entire computational domain by using the large source term technique (21). For instance, no hydrogen or oxygen virtually exist in the membrane and in this region a sufficiently large source term is assigned to the hydrogen or oxygen transport equation, which freezes the hydrogen or oxygen mole fraction at zero. Stringent numerical tests were performed to ensure that the solutions were independent of the grid size. The coupled set of equations was solved iteratively and the solution was considered to be convergent when the relative error in each field between two consecutive iterations was less than $10^{-6}$.

\section{RESULTS AND DISCUSSION}

Model validation is checked using numerical and experimental results in literature. The experimental setup input data in this model were used from Ref 10. In Fig. 2 the calculated results for polarization curve are compared and validated with the experimental results.

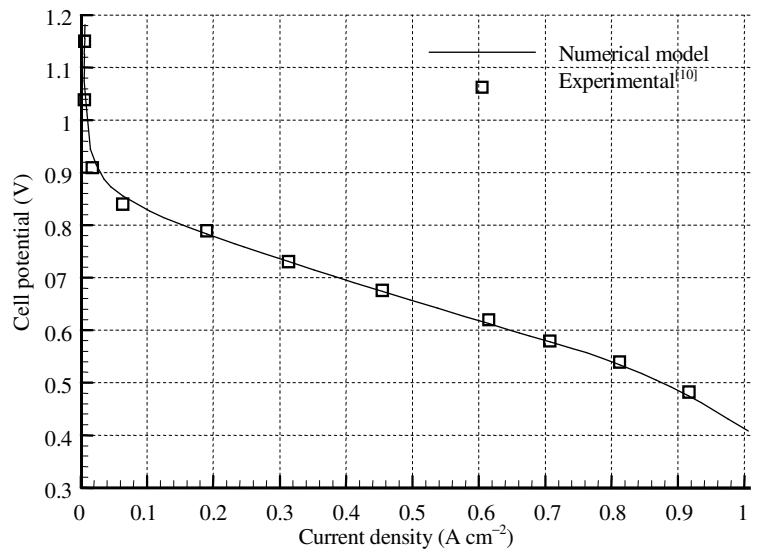

Fig. 2: Comparison between the numerical model and experimental results

The operating temperature range in the PEM fuel cell is between $333-363 \mathrm{~K}$. In this range, many parameters consist of operating cell voltage, cell operating temperature, feed gas relative humidity and thermal conductivity of the GDL that are expected to dominate the thermal behavior of the PEM fuel cell are investigated. The temperature rises within a cell is due to heat, Joule heating and the water phase change. The temperature changes $\left(T_{c}=353 \mathrm{~K}\right)$ across the entire cell for different current density are shown in Fig. 3. At low current density of $0.1 \mathrm{~A} / \mathrm{cm}^{2}$ the temperature variation across the cell is not significant. At higher current density of $0.7-1.1 \mathrm{~A} \mathrm{~cm}^{-2}$, it becomes almost linear in the 


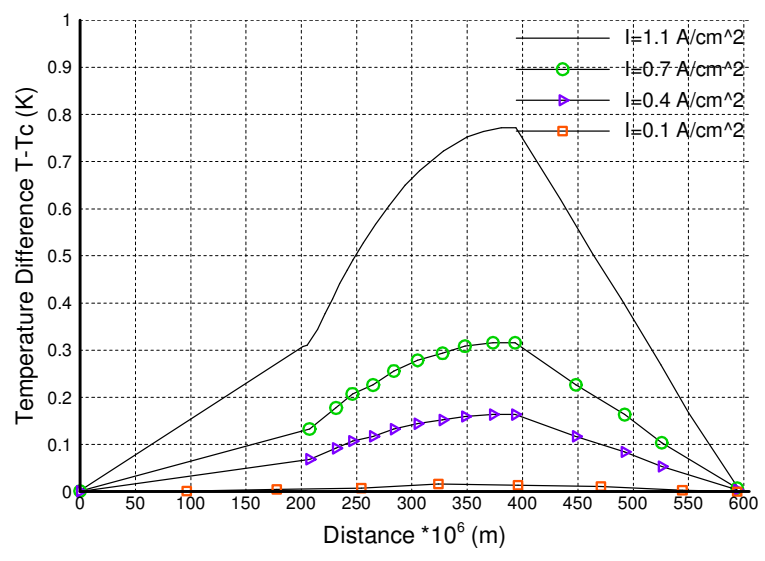

Fig. 3: Temperature distribution across the entire cell for different current density

anode and cathode electrode, indicating that heat transport is dominated by conduction in these regions with negligible heat generation due to Joule heating. The cathode side temperature is higher than the anode side. This is due to heat generation by the reaction in the cathodic catalyst layer, which is much larger than heat generation in the anode side. The maximum temperature occurs in the cathode catalyst layer since major heat generation takes place in this region. The temperature distribution within the membrane is not linear due to significant heat generation of Joule heating. The vaporization of liquid water result at higher temperatures within the cell, which, coupled with the electro-osmotic drag of water from the anode to the cathode side, will cause dehydration of the membrane on the anode side. Membrane dehydration will increase the resistance to proton migration and heat generation in the membrane. This makes membrane hydration a critical parameter governing the cell performance.

In order to provide a larger quantitity of water vapor for membrane hydration, gas streams are introduced into the cell at temperatures above the cell operating temperature. This technique will result in the condensation of excessive water vapor present, accompanied with heat release in the cell, thus, potentially increasing the temperature. The cell polarization curves at normal operating temperatures between 333 and $363 \mathrm{~K}$ are shown in Fig. 4. Extreme low or high operating temperatures hamper cell performance. At low operating range 333 and $343 \mathrm{~K}$ a drop in cell potential is obvious when compared with optimum operating temperature, $353 \mathrm{~K}$, where resistive losses in the membrane are increased. Improvement in cell potential with increasing operating temperature may be explained by the reduced losses in the cell and increase of ionic

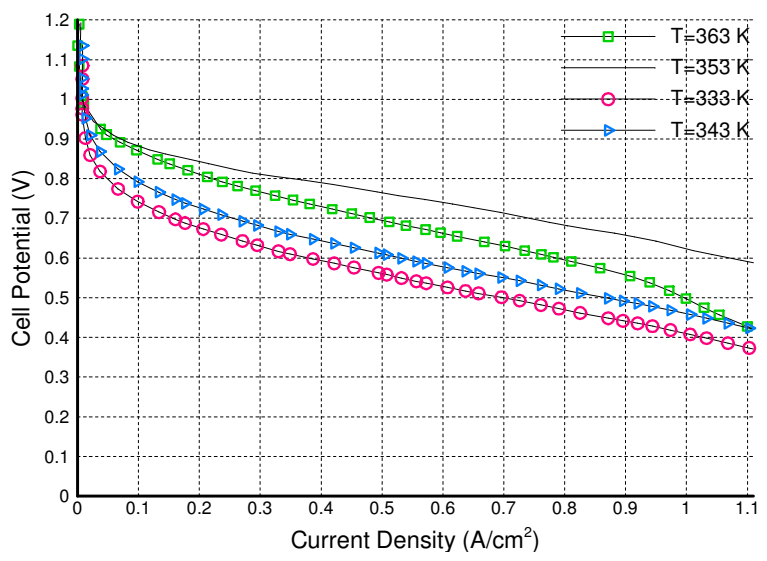

Fig. 4: Cell polarization curves for different operating temperatures

conductivity with increasing temperature, which leads to smaller resistive loss in the membrane. Although increasing the operating temperature can reduce ohmic, transport and activation losses, at the temperatures higher $353 \mathrm{~K}$ such as $363 \mathrm{~K}$ reduces cell potential basically due to an increased water vapor partial pressure, leading to enhanced mass transport related losses. Also excess operating temperature could lead to dehydration and cause reduction ionic conductivity and this could lead to excess thermal stress which may cause membrane rupture. In other words, at the temperatures higher $353 \mathrm{~K}$, the water content of the polymer membrane dramatically diminishes for fully humidified inlet flows and so the electrolyte overpotential increases. Hence, the temperature may have a positive effect on the reduction of the oxygen, but the higher proton resistance produced by the electrolyte dehydration at high temperatures has a dominant influence on the cathode reduction reaction. Obviously it is concluded that $353 \mathrm{~K}$ is optimum operating condition for the case studied.

At low operating temperature such as $333 \mathrm{~K}$ tends to give the highest peak temperature, but at higher temperature such as $363 \mathrm{~K}$ this peak reduces lower than $353 \mathrm{~K}$. This temperature distribution which is clearly shown in Fig. 3, 5-7 could be due to interaction of losses within the PEM fuel cell. Also it is shown by increasing the operating temperature the curve tends to recede and to become flat which cell temperature could be less dependent to operating temperature. Since multiple cells are stacked together in typical application, the seemingly small temperature rise within a single cell and the temperature jump across the cell interface caused by contact resistance may accumulate, thereby the effects of temperature in a complete fuel cell stack could be significant. 


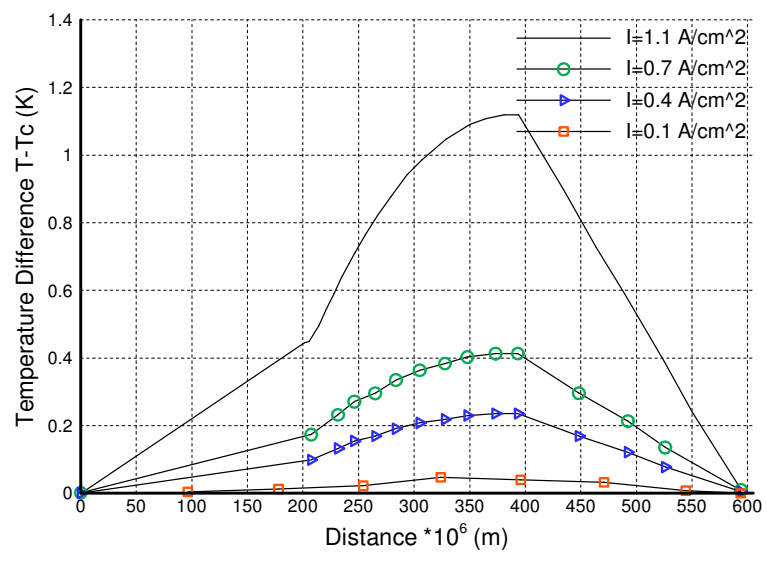

Fig. 5: Temperature distribution for different current density and operating temperature of $333 \mathrm{~K}$

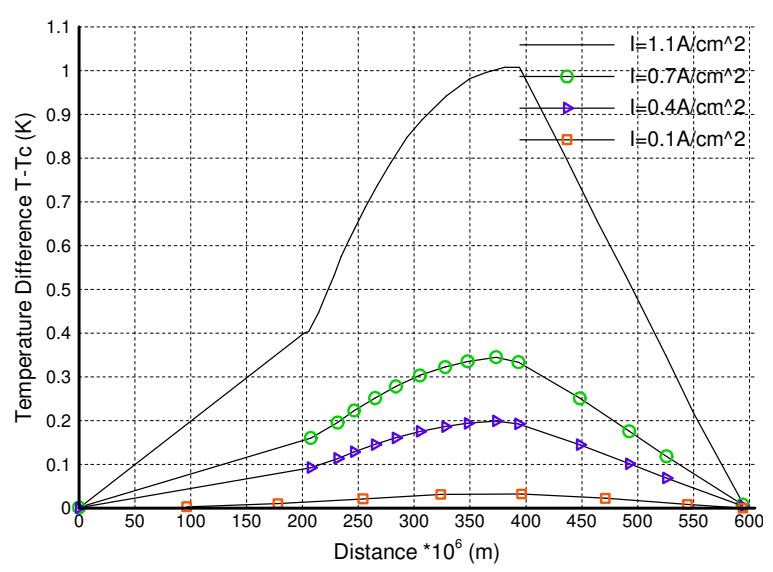

Fig. 6: Temperature distribution for different current density and operating temperature of $343 \mathrm{~K}$

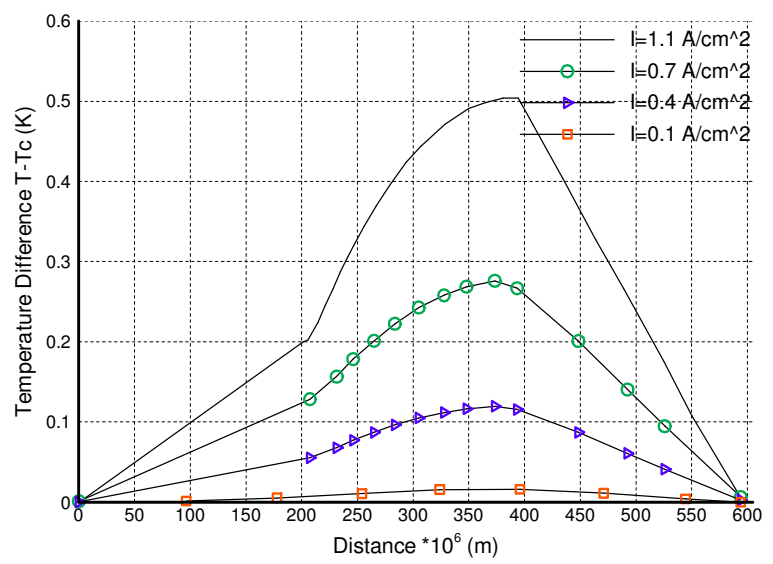

Fig. 7: Temperature distribution for cell operating temperature of $363 \mathrm{~K}$

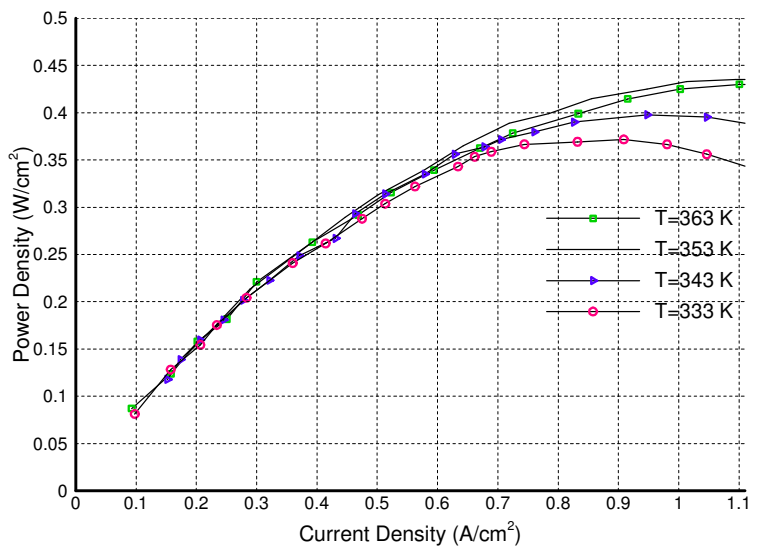

Fig. 8: Power density curve for different operating temperature

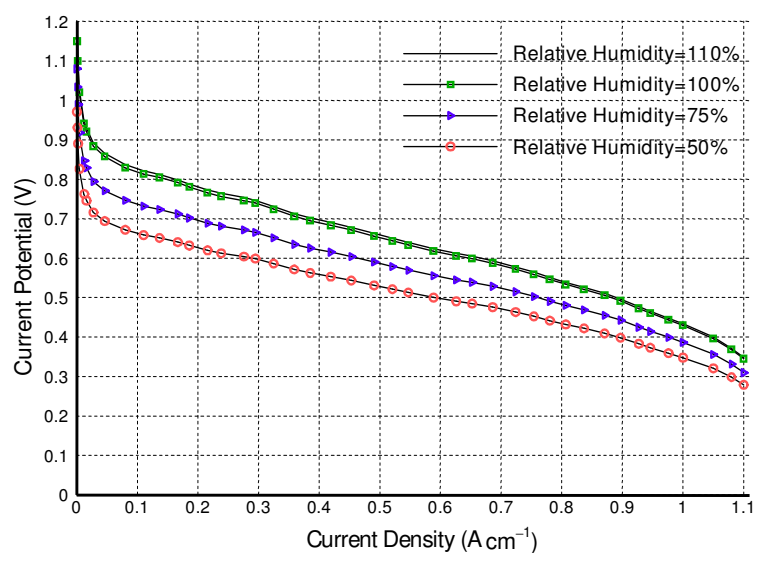

Fig. 9: Cell polarization curves for different relative humidity

The effect of the operating temperature on the power density which is similar to that of fuel cell potential is shown in Fig 8. High temperature tends to increases water vaporization in the PEM fuel cell. This could cause dehydration of membrane on the anode side and in turn it would increase the resistance to proton migration, resulting in even more heat generation. A significant parameter influencing thermal behavior is the feed gas relative humidity, as inlet humidification strongly affects the degree of overall membrane hydration. The proton conductivity of the membrane is directly proportional to water activity, indicating the more important role of the temperature distribution in low-humidity operation. The effects of the relative humidity of feed stream on the performance of the PEM fuel cell is shown in Fig. 9. The increase in relative humidity improves cell potential due to improved hydration and reduced ohmic losses. There is no 


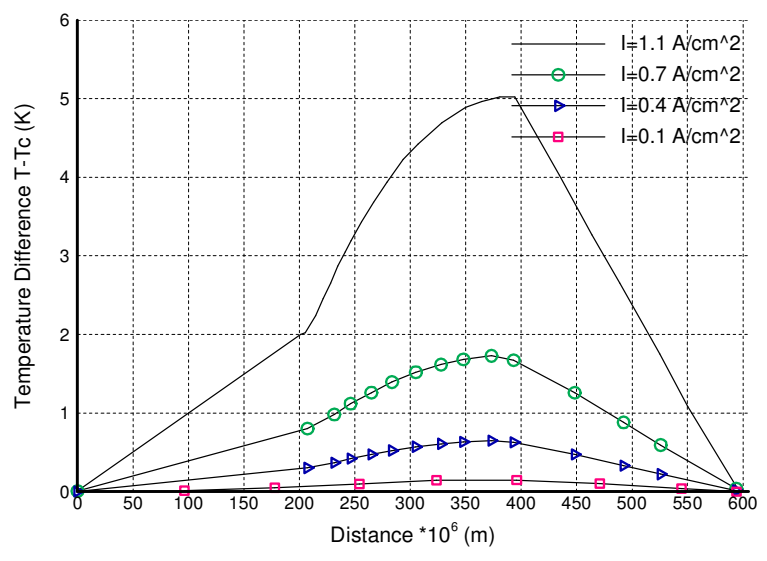

Fig. 10: Temperature distribution across the entire cell for different current density, $\mathrm{k}_{\mathrm{GDL}}=0.4 \mathrm{~W} / \mathrm{mK}$

significant improvement in cell potential for relative humidity between $100-110 \%$. Since the excess saturated water vapor condensed in the anode electrode and the actual water vapor concentration in the anode catalyst layer is could not exceed $100 \%$.

In case the inlet flows are not well humidified, voltage losses from the electrolyte may increase and have a high negative influence on the cathode reaction rate, as a result of the decrease of proton conductivity of the polymer electrolyte, which depends linearly on the water content. If the water content decreases, then the cathode overpotential increases, due to the increment of proton resistance and so the cathode reaction rate. The voltage loss induced by the polymer membrane is also increased, as product of the dehydrating conditions. The effect of water condensation in the cell is the most prominent at low current density. This is because at low current densities Joule heating and heat of reaction is small and the heat of condensation dominates. However, Joule heating increases significantly with the current density and becomes dominant at high current densities. At high current density this effect is less, because of reduced membrane resistivity due to better hydration.

The conductivity of the gas diffusion layers has a strong influence on the membrane temperature and hence on activation overpotential or the current distribution, indicating a significant role played by lateral heat conduction. In this section a simulation for different thermal conductivities were performed to assess its effect. Fig. 3, 10 and 11 show the changes in the temperature profiles when electronic conductivity decrease (or reduced electrode thickness). It is shown that the temperature profile within cell is much higher with reduced thermal conductivities and the peak

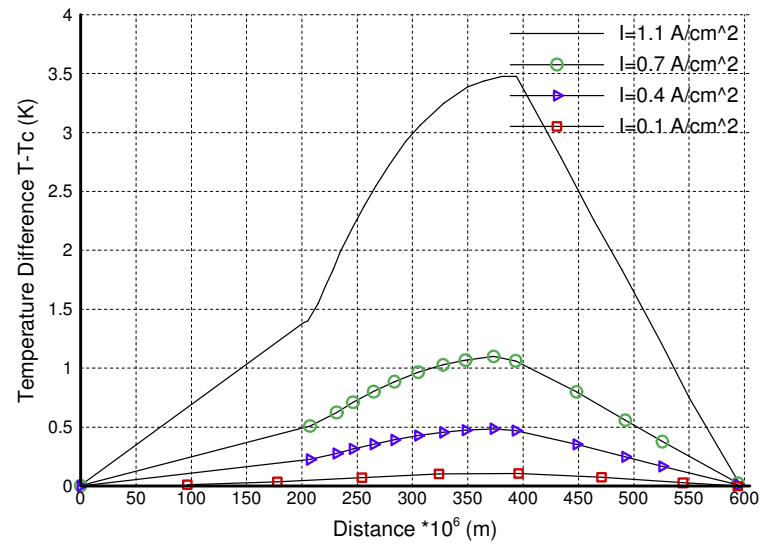

Fig. 11: Temperature distribution across the entire cell for different current density, $\mathrm{k}_{\mathrm{GDL}}=0.8 \mathrm{~W} / \mathrm{mK}$

temperature difference becomes nearly $5 \mathrm{~K}$ at $1.1 \mathrm{~A} / \mathrm{cm}^{2}$, because ohmic losses through the electrode decrease and the concentration losses become larger relative to the ohmic losses. In addition, results show that the GDL thermal conductivity strongly impacts the membrane temperature rise and thus plays an important role in coupled thermal and water management of PEM fuel cells.

\section{CONCLUSION}

A one-dimensional, single-domain, two-phases and non-isothermal model of a PEM fuel cell has been developed to investigate thermal management and effects on cell performance. Thermal response and water management have been investigated. The thermal management and water management is coupled. A study was performed for four critical parameters: current density, operating temperature, relative humidity and thermal conductivity of gas diffusion layer. The results show that at low current density the temperature variation across the cell is not significant but at high current density it becomes almost linear in the GDL and not linear within the membrane. The maximum temperature occurs in the cathode catalyst layer since major heat generation takes place in this region. Extreme low or high operating temperatures hamper cell performance and $353 \mathrm{~K}$ is optimum operating condition for the PEM fuel cell. Also the increase in relative humidity improves cell potential but, there is no significant improvement in cell potential for high relative humidity. The conductivity of the gas diffusion layers has a strong influence on the membrane temperature and the temperature profile within cell is much higher with reduced thermal conductivities. 


\section{NOMENCLATURE}

\begin{tabular}{|c|c|c|}
\hline Concentration $\left(\mathrm{moL} \mathrm{m}^{-3}\right)$ & $=$ & $\mathrm{c}$ \\
\hline Specific heat capacity (JFT kg ${ }^{-1} \mathrm{~K}$ ) & $=$ & $c_{p}$ \\
\hline Diffusivion coefficient $\left(\mathrm{m}^{2} \mathrm{~s}^{-1}\right)$ & $=$ & $\mathrm{D}$ \\
\hline Farraday constant $\left(\mathrm{C} \mathrm{moL}^{-1}\right)$ & $=$ & $\mathrm{F}$ \\
\hline Enthalpy of vaporization $\left(\mathrm{j} \mathrm{kg}^{-1}\right)$ & $=$ & $\mathrm{h}_{\mathrm{vap}}$ \\
\hline Exchange current density $\left(\mathrm{A} \mathrm{m}^{-2}\right)$ & $=$ & $\mathrm{i}_{0}$ \\
\hline Transfer current $\left(\mathrm{A} \mathrm{m}^{-3}\right)$ & $=$ & $\mathrm{j}$ \\
\hline thermal conductivity $\left(\mathrm{W} \mathrm{mK}^{-1}\right)$ & $=$ & $\mathrm{k}$ \\
\hline Hydraulic permeability $\left(\mathrm{m}^{2}\right)$ & $=$ & $\mathrm{K}$ \\
\hline Number of electrons & $=$ & $\mathrm{n}$ \\
\hline Pressure (pa) & $=$ & $\mathrm{P}$ \\
\hline Universal gas constant $\left(\mathrm{J} \mathrm{moL}^{-1} \mathrm{~K}\right)$ & $=$ & $\mathrm{R}$ \\
\hline Saturation & $=$ & $\mathrm{s}$ \\
\hline Source term in transport equation & $=$ & S \\
\hline thickness (m) & $=$ & $\mathrm{t}$ \\
\hline Temperature $(\mathrm{K})$ & $=$ & $\mathrm{T}$ \\
\hline Mass average velocity $\left(\mathrm{m} \mathrm{s}^{-1}\right)$ & $=$ & $\mathrm{u}$ \\
\hline Cell potential $(\mathrm{V})$ & $=$ & $\mathrm{V}_{\text {cell }}$ \\
\hline Thermodynamic equilibrium potential (V) & $=$ & $\mathrm{U}_{0}$ \\
\hline \multicolumn{3}{|l|}{ Greek letters } \\
\hline Porosity & $=$ & $\varepsilon$ \\
\hline potential (V) & $=$ & $\varphi$ \\
\hline \multicolumn{3}{|l|}{ Subscripts } \\
\hline Anode & $=$ & $\mathrm{a}$ \\
\hline Activation & $=$ & act \\
\hline Cathode & $=$ & c \\
\hline Dissolve & $=$ & diss \\
\hline Electro-osmotic drag & $=$ & drag \\
\hline Darcy pressure loss & $=$ & Dar \\
\hline Evaporation & $=$ & evap \\
\hline Liquid & $=$ & 1 \\
\hline Membrane & $=$ & $\mathrm{m}$ \\
\hline Ohm & $=$ & ohmic \\
\hline Protonic current & $=$ & $\mathrm{pc}$ \\
\hline Reversible & $=$ & rev \\
\hline Saturation & $=$ & sat \\
\hline Vapor & $=$ & vap \\
\hline water vaporization & $=$ & wV \\
\hline \multicolumn{3}{|l|}{ Superscripts } \\
\hline Effective & $=$ & eff \\
\hline Gas & $=$ & $\mathrm{g}$ \\
\hline Reference & $=$ & ref \\
\hline
\end{tabular}

\section{REFRENCES}

1. Peng, J. and S.J. Lee, 2006. Numerical simulation of proton exchange membrane fuel cells at high operating temperature. J. Power Sources, 162: 1182-1191.

2. Um, S., C.Y. Wang and K.S. Chen, 2000. Computational fluid dynamics modeling of proton exchange membrane fuel cells. J. Electrochem. Soc., 147: 4485-4493.

3. You, L. and H. Liu, 2002. A two-phase flow and transport model for the cathode of PEM fuel cells. Int. J. Heat Mass Transfer, 45: 2277-2287.

4. Ju, H., C.Y. Wang and S.U. Beuscherb, 2006. Nonisothermal Modeling of Polymer Electrolyte Fuel Cells, II. Parametric Study of LowHumidity Operation. J. Electrochem. Soc., 153 (2): A249-A254.

5. Hwang, J.J., 2007. A complete two-phase model of a porous cathode of a PEM fuel cell. J. Power Sources, 164: 174-181.

6. You, L. and H. Liu, 2002. A two-phase flow and transport model for the cathode of PEM fuel cells. Int. J. Heat Mass Transfer, 45: 2277-2287.

7. Senn, S.M. and D. Poulikakos, 2005. Multiphase Transport Phenomena in the Diffusion Zone of a PEM Fuel Cell. J. Heat Transfer, 127: 1245-1259.

8. Siegel, N.P., M.W. Ellis, D.J. Nelson and Spakovsky, M. R., 2003. Single domain PEMFC model based on agglomerate catalyst geometry. J. Power Sources., 115: 81-89.

9. Siegel, N.P., M.W. Ellis, D.J. Nelson and Spakovsky, M.R., 2004. A two-dimensional computational model of a PEMFC with liquid water transport. J. Power Sources., 128: 173-184.

10. Rowe, A. and X. Li, 2001. Mathematical modeling of proton exchange membrane fuel cells. J. Power Sources., 102: 82-96.

11. Pasaogullari, U., P. Mukherjee, C.Y. Wang and K.S. Chenc, 2007. Anisotropic Heat and Water Transport in a PEFC Cathode Gas Diffusion Layer. J. Electrochem. Soc., 154 (8): B823-B834. 